\title{
STRUKTURASI KONFLIK PENYESUAIAN TEMUAN AUDIT MELALUI PENELITIAN HUBUNGAN ANTARA AUDITOR DENGAN KLIEN
}

\author{
Jane Abigail \\ Institut Bisnis dan Informatika Kwik Kian Gie \\ abigail1_10@yahoo.com \\ Carmel Meiden \\ Institut Bisnis dan Informatika Kwik Kian Gie \\ cmeiden2@yahoo.com
}

\begin{abstract}
The purpose of this study is to understand the meaning of structuration adjustment audit findings conflict, to examine the terms of the roles and relationships between the auditor and management of their clients in the process of audit completion. Structuration theory states that the perpetrator and interrelated structure, no structure without actors, as there is no action without structure. The object of this research is a public accounting firm and the client where researchers work, as the number of informants in this study is five people. This study uses a phenomenological approach, because this research is directly related to the symptoms that occur in the sphere of organized human interaction. The method used in this research is qualitative. The results of the study reflect that the relationship between the auditor and the client has two principal types, namely proactive and reactive. Clients tend to perform reactive action during conflicts in the adjustment of the audit findings, so that there will be formal and informal actions in these interactions that will influence the outcome of the audit.
\end{abstract}

Keywords: Structuration, Conflict Adjustment Audit Findings, Phenomenology, Social Interaction.

\section{PENDAHULUAN}

\subsection{Latar Belakang Penelitian}

Tugas utama seorang auditor adalah melaksanakan audit dan memberikan opininya atas suatu laporan keuangan perusahaan dengan didasarkan pada pendidikan, pengalaman, dan pelatihan yang dimilikinya, serta dengan sikap yang kompeten, objektif, dan tidak memihak. Seorang auditor yang jujur, tegas, berpotensi, dan bekerja tanpa tekanan atas permintaan pihak tertentu/ kepentingan pribadinya akan dapat mempertahankan integritas.

Auditor memiliki tanggung jawab kepada publik, sehingga apabila terjadi konflik kepentingan di dalam Kantor Akuntan Publik maka Auditor dapat menjadi individu yang tetap mempertahankan tanggung jawab yang dimiliki kepada publik dan tetap menjaga independensi dalam hasil audit yang dilakukan.

Semua area profesi auditor saat ini terus menerus dihadapkan pada situasi sulit yang penuh dilemma etika yang melibatkan pilihan antara nilai - nilai yang bertentangan dimana kesadaran etik punya peranan yang sangat penting. Dilema etika sendiri memiliki artian dimana situasi yang dihadapi seseorang dimana keputusan mengenai perilaku yang pantas harus dibuat. Dilema ini terjadi pada saat auditor dan klien tidak sepakat terhadap beberapa fungsi dan tujuan pemeriksaan yang akhirnya menyebabkan auditor berada dalam situasi konflik.

Jika auditor memenuhi tuntutan klien berarti melanggar standart kode etik, tetapi jika tidak memenuhi tuntutan klien maka bisa menghasilkan sanksi baik bagi atsannya maupun dari kliennya berupa penghentian kerja atau pemutusan hubungan kerja. Oleh sebab itu kesadaran moral masing - masing individu yang berlandaskan pada nilai keyakinan individu yang memainkan peranan yang sangat penting dalam pengambilan kesimpulan. 
Jika auditor berada dalam situasi konflik penting bagi auditor untuk mempertahankan sikap independensi dalam pemeriksaan laporan keuangan perusahan, jika auditor tidak bersikap independen maka itu akan mempengaruhi integritas laporan keuangan yang akan sulit dicapai. Dikarenakan akan sulit mendapatkan pandangan objektif dan solusi yang terbaik untuk setiap permasalahan yang ada.

Windsor dan Ashkansy (1995) menyatakan bahwa dari wawancara yang mereka lakukan terhadap partner audit senior dari kantor akuntan publik multinasional papan atas, mereka memperoleh bukti bahwa partner audit menekankan pentingnya kemampuan auditor untuk menyeimbangkan antara etika professional dengan manfaat ekonomi bagi kelangsungan hidup kantor akuntan yang bersangkutan.

Dalam kode etik diungkapkan, akuntan tidak hanya memiliki tanggung jawab terhadap klien yang membayarnya saja, akan tetapi memiliki tanggung jawab juga terhadap publik. Kepentingan publik didefinisikan sebagai kepentingan masyarakat dan institusi yang dilayani secara keseluruhan. Publik akan mengharapkan akuntan untuk memenuhi tanggung jawabnya dengan integritas, obyektifitas, keseksamaan profesionalisme, dan kepentingan untuk melayani publik.

Auditor harus melaksanakan kewajiban untuk bersikap jujur tidak hanya kepada manajemen dan pemilik perusahaan, namun juga kepada kreditor dan pihak lain yang meletakkan kepercayaan atas laporan keuangan auditan. Hal inilah yang menarik untuk diperhatikan bahwa profesi akuntan publik ibarat pedang bermata dua. Disatu sisi auditor harus memperhatikan kredibilitas dan etika profesi, namun disisi lain auditor juga harus menghadapi tekanan dari klien dalam berbagai pengambilan keputusan. Jika auditor tidak mampu menolak tekanan dari klien seperti tekanan personal, emosional atau keuangan maka independensi auditor telah berkurang dan dapat mempengaruhi kualitas audit.

Menurut Roeslender dan Dillard (2003:327), Mengatakan bahwa “ Pada dasarnya, proyek Perspektif Indispliner dalam accounting memerlukan melihat akuntansi melalui berbagai disiplin." Interdispliner telah menjadi ciri khas dari penelitian akademik akuntansi dengan meminjam teori dan metodologi dari disiplin ilmu yang lainnya.

Dalam penugasan audit, pihak auditor akan berinteraksi dengan pihak manajemen dari perusahaan yang diaudit. Relasi atau hubungan antara kedua pihak akan menarik untuk diamati terutama dalam hal apa yang terjadi pada saat penyelesaian proses audit. Rumusan masalah dalam penelitian adalah:

Tujuan penelitian ini adalah mengamati, memahami, dan memperoleh kesimpulan bagaimana sebenarnya strukturasi konflik penyesuaian temuan audit, dengan meneliti dari sisi peran dan hubungan antara auditor dengan manajemen kliennya.

\subsection{Perumusan Masalah}

Berdasarkan latar belakang tersebut, maka penelitian ini akan menguji bagaimana strukturasi konflik penyesuaian temuan audit, dengan meneliti dari sisi peran dan hubungan antara auditor dengan manajemen kliennya dalam proses penyelesaian audit?

\section{TINJAUAN PUSTAKA DAN HIPOTESIS}

\subsection{Proses Audit}

Proses audit adalah suatu metodologi yang tersusun dengan baik dalam mengorganisasikan suatu audit untuk memastikan bahwa bukti - bukti yang telah terkumpul telah memadai dan kompeten serta semua tujuan audit yang tepat telah terspesifikasi dan terpenuhi. Menurut Arens, Elder, \& Beasley (2011), proses audit meliputi 4 tahap, antara lain:

1) Merencanakan dan merancang pendekatan audit

Dalam menentukan pendekatan audit yang akan digunakan, auditor harus mempertimbangkan 2 hal, yaitu bukti yang memadai dan kompeten harus terkumpul untuk memenuhi tanggung jawab professional auditor, serta biaya pengumpulan bukti tersebut harus seminimal mungkin. Berdasarkan pertimbangan tersebut, auditor harus membuat 
perencanaan yang menghasilkan suatu pendekatan audit yang efektif pada tingkat biaya yang wajar.

Dalam perencanaan dan perancangan pendekatan audit, terdapat dua aspek penting yang harus diperhatikan. Pertama, memperoleh pemahaman tentang proses dan strategi bisnis klien serta menilai resiko. Pemahaman atas strategi bisnis dan proses klien sangat penting agar dapat menilai risiko misstatement dalam laporan keuangan secara memadai dan menafsirkan informasi yang diperoleh selama audit. Kedua, memahami pengendalian internal dan menilai risiko pengendalian. Pengendalian internal efektif yang dimiliki klien dapat mengurangi risiko misstatements dalam laporan keuangan sehingga dapat menghasilkan informasi keuangan yang andal. Apabila klien dinilai memiliki pengendalian internal yang efektif, jumlah bukti audit yang harus dikumpulkan dapat dikurangi secara signifikan.

2) Melakukan uji kendali dan uji substantif atas transaksi

Tujuan utama dari tahap kedua ini adalah untuk memperoleh bukti atas pengendalian spesifik yang mendukung penilaian risiko pengendalian dan pelaksanaan audit atas pengendalian internal pada pelaporan keuangan klien, serta memperoleh bukti atas ketepatan nilai moneter suatu transaksi. Untuk mencapai tujuan-tujuan tersebut, maka dilakukan uji kendali dan uji substantif. Uji kendali merupakan pengujian atas efektivitas pengendalian untuk menyesuaikan pengurangan tingkat risiko pengendalian yang direncanakan semula. Uji substantif merupakan pengujian atas pencatatan transaksi dengan melakukan verifikasi atas nilai moneter transaksi tersebut.

3) Melakukan prosdur analitis dan uji rincian saldo

Tujuan utama dari tahap ketiga ini adalah untuk memperoleh tambahan bukti yang memadai untuk menentukan apakah saldo akhir dan catatan dalam laporan keuangan telah disajikan secara wajar. Untuk mencapai tujuan tersebut, maka dilakukan prosedur analitis dan uji rincian saldo. Prosedur analitis merupakan evaluasi menggunakan perbandingan perbandingan serta berbagai hubungan untuk menilai apakah saldo akun-akun dan dta-data lainnya disajikan secara wajar. Uji rincian saldo merupakan prosedur audit yang bertujuan menguji apakah terdapat misstatement pada nilai-nilai moneter akun-akun dalam laporan keuangan.

4) Melengkapi proses audit dan menerbitkan laporan audit

Setelah auditor menyelesaikan seluruh prosedur pada setiap tujuan audit dan pada setiap akun dalam laporan keuangan pada tiga tahap sebelumnya, maka tahap terakhir yang harus dilakukan auditor adalah mengumpulkan seluruh informasi yang telah diperoleh untuk mencapai kesimpulan menyeluruh mengenai apakah laporan keuangan telah disajikan secara wajar sesuai dengan prinsip akuntansi yang berlaku umum. Dalam tahap ini auditor juga melakukan review atas kewajiban kontijensi dan subsequent event. Setalah proses audit selesai, akuntan publik harus menerbitkan sebuah laporan audit atas laporan keuangan klien kemudian mengkomunikasikan laporan audit kepada para pemilik kepentingan.

\subsection{Teori Strukturasi}

Menurut Giddens (2011:20) Teori strukturasi merupakan teori yang menepis dualism (pertentangan) dan mencoba mencari likage atau pertautan setelah terjadi pertentangan tajam antara struktur fungsional dengan konstruksionisme fenomenologis. Giddens tidak puas dengan teori pandangan yang dikemukakan oleh struktural-fungsional, yang menurutnya terjebak pada pandangan naturalistik. Pandangan naturalistik mereduksi aktor dalam stuktur, kemudian sejarah dipandang secara mekanis, dan bukan suatu produk kontengensi dari aktivitas agen. Tetapi Giddens juga tidak sependapat dengan konstruksionisme-fenomenologis, yang baginya disebut sebagai berakhir pada imperalisme subjek. Oleh karenanya ia ingin mengakiri klaimklaim keduanya dengan cara mempertemukan kedua aliran tersebut.

Giddens menyelesaikan debat antara dua teori yang menyatakan atau berpegang bahwa tindakan manusia disebabkan oleh dorongan eksternal dengan mereka yang menganjurkan tentang tujuan dari tindakan manusia Menurut Giddens, struktur bukan bersifat eksternal bagi 
individu-individu melainkan dalam pengertian tertentu lebih bersifat internal. Terkait dengan aspek internal ini Giddens menyandarkan pemaparannya pada diri seorang subjek yang memiliki sifatnya yang otonom serta memiliki andil untuk mengontrol struktur itu sendiri.

Giddens (2011:31) memaparkan, struktur tidak disamakan dengan kekangan (constraint) namun selalu mengekang (constraining) dan membebaskan (enabling). Hal ini tidak mencegah sifat-sifat struktur sistem sosial untuk melebar masuk kedalam ruang dan waktu diluar kendali actor-aktor individu, dan tidak ada kompromi terhadap kemungkinan bahwa teori-teori sistem sosial para aktor yang dibantu ditetapkan kembali dalam aktivitas-aktivitasnya bisa merealisasikan sistem-sistem itu.

Manusia melakukan tindakan secara sengaja untuk menyelesaikan tujuan-tujuan mereka, pada saat yang sama, tindakan manusia memiliki unintended consequences (konsekuensi yang tidak disengaja) dari penetapan struktur yang berdampak pada tindakan manusia selanjutnya. Manusia menurut teori ini yaitu agen pelaku bertujuan yang memiliki alasan-alasan atas aktivitas-aktivitasnya dan mampu menguraikan alasan itu secara berulangulang.

Tidak menutup kemungkinan alasan yang diuraikan oleh manusia secara berulang-ulang tersebut memiliki tujuan-tujuan yang didasarkan atas apa yang hendak ia perlukan pada dimensi ruang dan waktu yang berbeda-beda. Bisa dikatakan tindakan dari seorang agen tak jarang pula untuk mempengaruhi struktur di mana mereka tengah menjalankan kiprahnya.

Aktivitas-aktivitas sosial manusia ini bersifat rekursif dengan tujuan agar aktivitas-aktivitas sosial itu tidak dilaksanakan oleh pelaku-pelaku social tetapi diciptakan untuk mengekspresikan dirinya sebagai aktor atau pelaku secara terus menerus dengan mendayagunakan seluruh sumberdaya yang dimilikinya. Pada dan melalui akivitas-aktivitasnya, agen-agen mereproduksi kondisi-kondisi yang memungkinkan dilakukannya aktivitas-aktivitas itu.

Tindakan manusia diibaratkan sebagai suatu arus perilaku yang terus menerus seperti kognisi, mendukung atau bahkan mematahkan selama akal masih dianugerahkan padanya (Giddens, 2011:3).

\subsection{Dualitas Struktur}

Menurut Giddens (2011: 31) Struktur sebagai perangkat aturan dan sumberdaya yang diorganisasikan secara rekursif, berada diluar ruang dan waktu, disimpan dalam koordinasi dan kesegeraanna sebagai jejak-jejak memori yang ditandai oleh ketiadaan subjek. Sebaliknya sistem sosial tempat disiratkannya secara rekursif struktur terdiri dari aktivitas-aktivitas agen manusia daam situasi tertentu yang direproduksi dalam ruang dan waktu.

Menganalisis struktur sistem sosial berarti mengkaji mode-mode tempat diproduksi dan direproduksinya sistem-sistem seperti itu dalam interaksi yang didasarkan pada aktivitasaktivitas utama agen-agen di temapat tertentu yang menggunakan aturan-aturan dan sumberdaya-sumberdaya dalam konteks tindakan yang beraneka ragam. Yang paling penting dalam gagasan strukturasi ialah dualitas struktur yang secara logis disiratkan dalam argumentargumen yang dikemukakan di atas.

Pembentukan agen - agen dan struktur-struktur bukanlah dua gugus fenomena tertentu yang terpisah, yakni dualism, melainkan menggambarkan suatu bentuk dualitas. Menurut gagasan dualitas struktur sifat-sifat struktual sistem social keduanya merupakan media dan hasil praktek-praktek yang mereka organisasikan secara rekursif. Struktur tidaklah bersifat eksternal bagi individu-individu, sebagai jejak-jejak memori dan seperi yang diwujudkan dalam praktekpraktek sosial, namun dalam pengertian tertentu ia lebih bersifat 'internal' bukannya eksternal bagi aktivitas-aktivitasnya dalam pengertian Durkheim dengan fakta sosial.

Struktur tidak disamakan dengan kekangan namun selalu mengekang dan membebaskan. Tentu saja hal ini tidak mencegah sifat-sifat terstruktur sistem sosial untuk melebar masuk ke dalam ruang dan waktu di luar kendali aktor-aktor individu, juga tidak ada kompromi terhadap kemungkinan-kemungkinan bahwa teori sistem sosial para aktor dibantu ditetapkan kemabali dalam aktivitas-aktivitasnya bisa merealisasikan sistem-sistem itu. Reifikasi hubunganhubungan sosial atau naturalisasi diskursif keadaan-keadaan yang bergantung secara historis 
pada produk-produk tindakan manusia merupakan salah satu dimensi utama ideologi dalam kehidupan sosial (Giddens, 2011: 32).

Menurut Giddens (2011: 33) Dualitas struktur selalu merupakan dasar utama kesinambungan dalam reproduksi sosial dalam ruang dan waktu. Pada gilirannya hal ini mensyaratkan monitoring refleksif agen-agen dan sebagimana yang ada di dalam duree aktivitas sosial sehari-hari. Namun jangkauan pegetahuan manusia itu selalu terbatas. Arus suatu tindakan senantiasa mengahasilkan konsekuensi-konsekuensi yang tidak diinginkan oleh aktoraktor dan konsekuensi-konsekuensi yang tidak diinginkan itu mungkin juga membentuk kondisi-kondisi tindakan yang tak diakui dalam suatu umpan balik. Meski sejarah manusia diciptakan oleh aktivitas-aktivitas yang disengaja, namun ia bukanlah suatu proyek yang diinginkan, sejarah manusia senantiasa menghindarkan usaha-usaha untuk menggiringnya agar tetap berada di jalur kesadaran. Namun usaha-usaha semacam itu trus menerus dilakukan manusia, yang bekerja di bawah ancaman dari janji bahwa mereka adalah satu-satunya makhluk yang membuat sejarahnya dengan memperhatikan fakta di atas.

Sedikit banyak dualitas struktur telah memebri keterangan kita tentang bagaimana agen dan struktur berintegrasi dan membangun identitasnya yang baru yang juga didukung oleh pengetahuan latar, ruang dan waktu yang memiliki karakteristiknya tertentu. Tak berhenti sampai di situ, konsepsi mengenai legitimasi sangat patut kita turut campurkan dalam bersatunya agen dan struktur yang mebangun identitasnya yang baru. Legitimasi sangat terkait dengan penerimaan dan kesadaran. Di mana komunikasi intensif daripada agen dan struktur secara langgeng disadari dan pada akhirnya mereproduksi kententuan-ketentuan, nilai serta norma-norma yang baru. Gagasan ini memang lebih dirasa rasional ketika perjumpaan sosial dan sumberdaya menjadi peluang untuk mengontrol keadan sosial dikendaki untuk berubah bedasar atas agen-agen yang pintar dalam melihat situasi (Giddens, 2011: 36).

\subsection{Interpretif Sebagai Paradigma Penelitian}

Paradigma intrepretatif menganut pendirian sosiologi keteraturan seperti halnya fungsionalisme, tetapi mereka menggunakan pendekatan subjektivitisme dalam analisis sosialnya sehingga hubungan mereka dengan sosiologi keteraturan bersifat tersirat. Oleh karenanya pandangan ini ingin memaknai kenyataan social dalam realitas sesuai dengan apa adanya yang terjadi sesuai dengan yang dialami oleh manusia tersebut bukan menurut pengamatan yang dialami, melainkan pengalaman langsung yang terjadi pada dirinya.

Kaum intrepretif biasanya bersifat nominalis yaitu bahwa aktorlah yang mengalaminya, dan juga bersifat antipositivisme, voluntarisme, dan ideografis. Paradigma interpretif ini lebih menekankan kepada realitas social sebagai sesuatu yang hanya merupakan label, nama, atau konsep yang digunakan untuk membangun realitas, dan bukanlah sesuatu yang nyata, melainkan hanyalah penamaan atas sesuatu yang diciptakan oleh manusia atau merupakan produk manusia itu sendiri. Dengan demikian, realitas social merupakan sesuatu yang berada pada dalam diri manusia, sehingga bersifat subjektif bukan objektif.

Interpretif menyatakan situasi sosial yang mengandung ambiguisitas yang besar. Perilaku dan pernyataan memiliki banyak makna dan dapat diinterpretasikan dengan berbagai cara, antara lain: Penelitian naratif, fenomenologi, grounded theory, etnografi, studi kasus, dramaturgi, hermeneutik, interaksi simbolik, etnometodologi, dan critical discourse analysis.

Pendekatan interpretif merupakan upaya mencari penjelasan mengenai peristiwa peristiwa sosial atau budaya yang didasarkan pada perspektif dan pengalaman orang yang diteliti. Paradigma interpretif mengungkapkan bahwa prinsip - prinsip yang terdapat dalam ilmu alam tidak bisa diambil dan diimplementasikan begitu saja ke dalam ilmu - ilmu sosial. Karakteristik dari ilmu sosial sangatlah berbeda dengan karakteristik ilmu alam, sehingga bagi paham interpretif sumber dari perilaku sosial dalam tataran otonomi dianggap tidak terletak di luar aktor atau individu tersebut. Oleh sebab itu bahwa realitas sosial diartikan sebenarnya secara sadar dan secara aktif dibangun sendiri oleh individu - individu. Setiap individu mempunyai potensi dalam memberikan arti makna apa yang dilakukan dari setiap tindakannya sedangkan, realitas sosial adalah produk dari interaksi antar individu yang sangat sarat makna. 
Penelitian ini menggunakan paradigm interprtif dengan fenomenologi sebagai pendekatannya. Istilah fenomenologi secara etimologis berasal dari kata fenome dan logos. Fenomena berasal dari Bahasa Yunani phainomenon yang berarti menampakkan diri dan logos yang artinya akal budi. Ilmu tentang penampakan berarti ilmu tentang apa yang menampakkan diri ke pengalaman subjek. Secara harafiah fenomena diartikan sebagai gejala atau sesuatu yang menampakkan.

\section{METODE PENELITIAN}

\subsection{Objek Penelitian}

Objek penelitian pada penelitian ini adalah senior auditor, manager, partner, dan klien dari tempat peneliti bekerja. Untuk wawancara dilakukan di Kantor Akuntan Publik tempat peneliti bekerja dan Kantor Klien dari Kantor Akuntan Publik tempat peneliti bekerja.

Data yang digunakan dalam penelitian adalah data primer. Menurut Sugiyono (2009:402) yang dimaksud dengan data primer adalah sumber data yang langsung memberikan data kepada pengumpul data. Data primer yang digunakan adalah dengan teknik wawancara.

\subsection{Desain Penelitian}

Penelitian ini menggunakan pendekatan fenomenologi, karena penelitian ini terkait langsung dengan gejala-gejala yang terjadi dalam lingkup interaksi manusia terorganisasi. Menurut Creswell (2007: 60-62), secara umum prosedur penelitian fenomenologi adalah sebagai berikut:

a. Menentukan apakah masalah penelitian ini paling cocok didekati dengan studi fenomenologi. Jenis masalah yang paling cocok dengan bentuk penelitian ini adalah penting untuk memahami pengalaman beberapa individu terhadap fenomena agar dapat mengembangkan pemahaman yang mendalam terhadap fitur fenomena tersebut.

b. Identifikasi fenomena yang menarik untuk diteliti, seperti kemarahan, profesionalisme, apa artinya menjadi kurus, atau apa artinya menjadi pengulat, dan sebagainya.

c. Mengenal dan menetapkan asumsi filosofis dan fenomenologi. Sebagai contoh, seseorang dapat menulis tentang kombinasi antara tujuan realitas dan pengalaman individu. Pengalaman individu jauh lebih "sadar"dan terarah terhadap objek.

d. Mengumpulkan data yang berasal dari individu-individu yang telah mengalami fenomena. Pengumpulan data dalam studi fenomenologi biasanya terdiri dari wawancara secara mendalam dan berkali-kali dengan informan.

e. Mengajukan dua pertanyaan umum kepada narasumber, seperti apa yang telah anda alami berkaitan dengan fenomena tersebut? Situasi apa yang mempengaruhi pengalaman anda terhadap fenomena?

f. Langkah-langkah analisis data fenomenologi secara umum sama untuk semua fenomenologi secara psikologis yang mendiskusikan metode-metode tersebut. Selanjutnya, peneliti mengembangkan kelompok makna dari pernyataan yang signifikan ke dalam tema.

g. Pernyataan yang signifikan dan tema tersebut kemudian digunakan untuk menulis deskripsi mengenai apa yang informan alami (textural description) dan situasi yang mempengaruhi bagaimana informan mengalami fenomena itu (structural description).

h. Dari structural description dan textural description, peneliti selanjutnya menulis sebuah deskripsi komposit yang menghadirkan esensi fenomena yang dialami.

Penelitian fenomenologis ini focus terhadap sesuatu yang dialami dalam kesadaran individu, yang disebut intensionalitas. Intensionalitas (intentionality), menggambarkan hubungan antara proses yang terjadi dalam kesadaran dengan obyek yang menjadi perhatian pada proses itu. Dalam pendekatan fenomenologi ini, peneliti hendak meneliti apa yang dialami manusia dari sudut pandang orang pertama, yakni orang yang mengalaminya. Fokus fenomenologi bukan pengalaman particular, melainkan struktur dari pengalaman kesadaran, yakni realitas objektif yang terwujud dalam pengalaman subjektif orang per orang. Fenomenologi berfokus pada makna subjektif dari realitas objektif di dalam kesadaran orang yang menjalani aktivitas kehidupannya sehari-hari. 


\subsection{Teknik Pengumpulan Data}

Teknik pengumpulan data yang dilakukan pada penelitian ini adalah teknik pengumpulan data langsung di lapangan. Pengumpulan data dilakukan dengan langsung mendatangi objek yang akan diteliti untuk memperoleh data primer.

Menurut Moleong (2010:186), metode yang digunakan dalam penelitian kualitatif, adalah:

a. Teknik Wawancara

Teknik wawancara merupakan percakapan dengan maksud tertentu yang dilakukan oleh dua belah pihak yaitu pewawancara (interviewer) yang mengajukan pertanyaan dan terwawancara (interviewee) yang memberikan jawaban atas pertanyaan. Metode wawancara ini bisa dikatakan pengamatan secara langsung yang dilakukan penulis.

Teknik wawancara yang digunakan dalam penelitian ini adalah wawancara mendalam (indepth interview) yang merupakan proses memperoleh keterangan untuk tujuan penelitian dengan cara melakukan tanya jawab sambil bertatap muka antara pewawancara dan terwawancara dengan pedoman (guide) wawancara atau tanpa menggunakan pedoman (guide) wawancara. Dalam wawancaranya, peneliti menggunakan metode wawancara terstruktur dan wawancara tidak terstruktur (Moleong, 2011). Dalam wawancara terstruktur peneliti menetapkan sendiri masalah dan pertanyaan-pertanyaan yang akan diajukan, sedangkan wawancara tidak terstruktur merupakan wawancara yang tidak terlalu baku, pertanyaan yang disampaikan dikhususkan kepada orang yang mendalaminya sehingga pertanyaan disesuaikan dengan keadaan dari ciri dari informan dan proses tanya jawabnya mengalir seperti percakapan sehari-hari.

Objek yang diwawancarai oleh peneliti ialah Kantor Akuntan Publik tempat peneliti bekerja yang terletak di Jakarta Pusat, dengan subyek yang diteliti ialah manager, partner, dan dua orang klien dari KAP tempat peneliti bekerja. Wawancara yang dilakukan oleh peneliti dilakukan secara individu dan bertatap muka secara langsung dengan terwawancaraya. Pertanyaan yang diajukan peneliti merupakan pertanyaan yang berkaitan dengan proses negosiasi audit yang terjadi pada saat temuan audit ditemukan dan kesesuaian dengan etika profesi yang ada. Tujuan dari waancara ini yaitu untuk menggali informasi yang mendalam yang digunakan dalam penelitian yang dilakukan oleh peneliti.

b. Teknik Observasi

Teknik observasi sebagai upaya peneliti untuk menyjikan gambaran realistik perilaku atau kejadian, menjawab pertanyaan, membantu mengerti perilaku manusia, dan evaluasi. Peneliti dalam melakukan pengamatan menggunakan pengamatan penuh dimana peneliti sebagai pengamat bebas mengamati seara jelas subyeknya dari belakang kaca sedangkan subyeknya tidak tahu sama sekali kalau mereka sedang diamati.

c. Teknik Dokumentasi

Teknik dokumentasi merupakan upaya untuk menganalisa dari data atau dokumen yang ada. Dokumentasi dilakukan bertujuan untuk mengetahui fakta dan fakta tersimpan dalam bentuk dokumentasi berupa surat-surat, catatan harian, laporan, foto, dan sebagainya. Sifat utama data ini tak terbatas pada ruang dan waktu sehingga memberi peluang kepada peneliti untuk mengetahui hal-hal yang pernah terjadi di waktu silam.

\section{HASIL PENELITIAN DAN PEMBAHASAN}

Berdasarkan proses pencarian tema, peneliti merangkum temuan-temuan yang diperoleh berdasarkan informasi dari informan. (lihat lampiran tabel 1.1)

\subsection{Aturan Yang Mengawasi Tindakan}

Laporan audit harus menyatakan apakah laporan keuangan telah disusun sesuai dengan prinsip akuntansi yang berlaku umum di Indonesia. Kepatuhan adalah suatu kondisi yang tercipta dan berbentuk melalui proses dari serangkaian perilaku yang menunjukkan nilai-niai ketaatan, kepatuhan, kesetiaan, keteraturan, dan ketertiban. 
Auditor bertanggung jawab untuk merencanakan dan melaksanakan audit untuk memperoleh keyakinan memadai tentang apakah laporan keuangan bebas dari salah saji material dan mendapatkan bukti yang memadai. Dalam mengamati standar auditing, auditor independen harus menggunakan pertimbangannya dalam menentukan prosedur audit yang diperlukan sesuai dengan keadaan, sebagai basis memadai bagi pendapatnya. Pertimbangannya harus merupakan pertimbangan berbasis informasi dari seorang profesional yang ahli.

Auditor independen juga bertanggung jawab terhadap profesinya, tanggung jawab untuk mematuhi standar yang diterima oleh para praktisi rekan seprofesinya. Dalam mengakui pentingnya kepatuhan tersebut. Dalam kasus yang dihadapi peneliti, pihak auditor dalam melaksanakan audit harus menyesuaikan dengan standar audit yang berlaku di Indonesia. Dalam menentukan temuan audit kita harus mempertimbangkan materialitas dari akun yang kita audit.

Dalam kasus klien ini mengalami masalah juga di asersi penyajian dan pengungkapan yang disebabkan oleh sifat bisnis di Indonesia yang memang sulit. Kelengkapan data saat prosedur audit vouching dilakukan tidak memadai karena tidak memiliki dokumen pendukung yang lengkap. Auditor memiliki tanggung jawab baik pihak internal dan pihak eksternal atas hasil audit dan juga profesionalisme yang harus dijaga saat melakukan penugasan audit. Laporan keuangan klien juga harus sesuai dengan standar pelaporan yang ada sehingga laporan tersebut memiliki kualitas yang baik dan mengandung informasi yang tidak menyesatkan para pembacanya. Seringkali terdapat juga konflik yang mempengaruhi keputusan auditor untuk mematuhi standar-standar yang ada.

Auditor biasanya mempertimbangkan hukum dan peraturan yang dipahaminya sebagai hal yang memiliki pengaruh langsung dan material dalam penentuan jumlah jumlah yang disajikan dalam laporan keuangan.

Dalam kasus ini kita dapat melihat hal-hal yang harus diperhatikan dan dilakukan saat penyelesian konflik audit sesuai dengan kasus yang dialami oleh peneliti. Kepatuhan akan standar merupakan hal yang terpenting dan menjadi fokus utama auditor dalam melakukan setiap penugasan audit.

\subsection{Penolakan Klien Atas Koreksi Temuan Audit}

Laporan keuangan adalah tanggungjawab manajemen atau klien. Audit atas laporan keuangan bertujuan untuk memberikan pendapat atas laporan keuangan yang disajikan oleh manajemen atau klien. Untuk dapat menerima perikatan audit, auditor berkepentingan untuk mengevaluasi integritas manajemen, agar auditor mendapatkan keyakinan bahwa manajemen perusahaan klien dapat dipercaya, sehingga laporan keuangan yang diaudit bebas dari salah saji material sebagai akibat dari adanya integritas manajemen.

Saat audit dilakukan seringkali ada perbedaan pendapat yang dialami yang diakibatkan oleh perbedaan kepentingan anatara auditor dan klien. Seringkali klien memiliki tujuan dan kepentingan tertentu, dalam kondisi tersebut umumnya timbul kesulitan saat harus melakukan penyesuaian pencatatan klien dengan standar akuntansi yang berlaku. Sehingga klien cenderung menghindari tanggung jawab dengan berbagai alasan.

Klien seringkali baik sengaja ataupun tidak salah dalam mengklasifikasikan suatu akun, sehingga menyebabkan aset dan pendapatan yang overstated serta hutang yang cenderung understated. Banyak juga klien yang melakukan penghindaran pajak sehingga membuat pelaporan yang tidak sesuai dengan standar akuntansi yang berlaku di Indonesia. Kondisi bisnis di Indonesia cenderung memiliki lingkungan yang tidak baik sehingga secara tidak sengaja klien harus melakukan penghindaran hukum karena terlibat didalamnya.

Laporan keuangan yang dibuat oleh klien bertujuan untuk pihak internal dan eksternal perusahaan, apabila klien meminjam uang dari pihak bank maka akan melampirkan laporan keuangan yang sudah diaudit oleh auditor indepnden serta lampiran untuk pelaporan perpajakan, sehingga disitu timbul kewajiban kepada pihak eksternal untuk memberikan pelaporan keuangan secara berkala. 


\subsection{Kesepakatan Baru}

Peran keseluruhan dari auditor adalah mengelola hubungan/relasi dan hal ini dinilai oleh semua pihak sebagai hal yang baik. Hubungan/relasi antara auditor dan manajemen klien mempunyai dua tipe yang prinsipiil yakni: proaktif dan reaktif . Dalam hubungan proaktif peran auditor adalah sebagai expert advisor, sedangkan dalam hubungan reaktif peran auditor adalah sebagai pollice officer. Auditor menyadari bahwa akan lebih baik hubungan dengan klien adalah proaktif yaitu posisi ideal bagi auditor dan klien, peran auditor sebagai expert advisor membuat hubungan auditor dan klien tidak mengalami konflik melainkan auditor sebagai expert advisor dan klien tidak melakukan negosiasi atau kecurangan sehingga auditor tidak berada dalam posisi yang sulit dan tidak diperlukan adanya negosiasi dan konflik.

Apabila klien melakukan tindakan reaktif maka akan terjadi negosiasi dan adanya tindakan formal dan non formal dalam negosiasi tersebut. Klien akan memberikan alasan yang formal mengenai penyimpangan atau ketidakseusaian yang terjadi saat temuan audit didapatkan dan apabila auditor menggali kecurangannya tersebut maka klien cenderung untuk melakukan tindakan negosiasi non formal yang cenderung dipaksakan dan dengan alasan yang tidak relevan.

Dalam proses negosiasi non formal klien akan mengungkapkan alasan yang jujur tentang penyimpangan atau kesalahan yang sengaja dibuat klien. Klien meminta auditor untuk memenuhi kebutuhannya tersebut. Klien yang dihadapkan dengan auditor juga seringkali mengalami tekanan dari atasan mereka untuk memanipulasi laporan keuangan sehingga klien sebagai pelaku akan ditekan oleh struktur yaitu top management untuk mencapai tujuan tertentu yang diinginkan oleh perusahaan.

Di sisi lain staff auditor dan Manager juga mengalami tekanan dari pihak partner auditor. Partner audit sebagai struktur yang menentukan keputusan akhir mengenai hasil temuan audit. Staff auditor dan Manager akan bertindak sesuai dengan keputusan yang dibuat oleh struktur yaitu audit partner, sebagaimana tidak ada tindakan tanpa struktur.

Pihak auditor seringkali membantu klien secara sukarela untuk bernegosiasi dengan pihak klien, dan seringkali keputusan yang dibuat oleh Manager dan Partner tidak seusai dengan standar akuntansi yang berlaku. Sikap Manager dan Partner ini juga salah satunya disebabkan oleh tekanan negosiasi non formal dari klien.

Hasil reduksi transendental merefleksikan bahwa dalam menjaga etika profesi dibutuhkan sikap profesionalitas sebagai pegangan prinsip dari nilai - nilai aturan etika para informan untuk dapat melayani kepentingan publik. Sikap ini juga harus dikembangkan oleh sikap moralitas dari para akuntan yang bekerja di Kantor Akuntan Publk (KAP). Moralitas dari setiap para akuntan dapat menilai baik atau tidaknya suatu perbuatan tersebut, dan juga apakah pantas untuk dialakukan atau tidak. Moralitas dari para akuntan, dapat dilihat dari adanya nilai kebenaran. Nilai kebenaran ini merupakan nilai kebaikan seperti nilai kejujuran sehingga dengan sikap kejujuran tersebut dapat menimbulkan sikap profesionalitas dalam bekerja.

\section{SIMPULAN DAN KONTRIBUSI PRAKTIS}

\subsection{Simpulan}

Berdasarkan hasil analisis dan pembahasan dari wawancara yang dilakukan di KAP tempat peneliti bekerja, maka penelitian ini dapat disimpulkan masih banyak temuan dan tindakan penyimpangan yang dilakukan klien dalam proses pembuatan laporan keuangannya.

Auditor seringkali dihadapkan dengan situasi konflik audit diantaranya diakibatkan karena adanya ketidakberesan yang harus dilaporkan oleh auditor, seperti salah saji atau hilangnya jumlah dalam pengungkapan dalam laporan keuangan yang disengaja.

Negosiasi dilakukan antara auditor dan klien saat dihadapkan dengan konflik audit. Terdapat tindakan formal dan formal dari klien saat proses negosiasi. Auditor yang dihadapkan dengan klien yang seringkali mengalami tekanan dari atasan mereka untuk memanipulasi laporan keuangan sehingga klien sebagai pelaku akan ditekan oleh struktur yaitu top management untuk mencapai tujuan tertentu yang diinginkan oleh perusahaan. 
Di sisi lain staff auditor dan Manager juga mengalami tekanan dari pihak partner auditor. Partner audit sebagai struktur yang menentukan keputusan akhir mengenai hasil temuan audit. Staff auditor dan Manager akan bertindak sesuai dengan keputusan yang dibuat oleh struktur yaitu audit partner, sebagaimana tidak ada tindakan tanpa struktur.

Nilai kejujuran dan profesionalitas harus tetap dipertahankan ditengah tekanan yang dihadapi saat adanya konflik penyesuaian temuan audit. Dalam menunjang sikap profesional, kode etik ini harus ditaati oleh para akuntan, yaitu pemimpin KAP, termasuk di dalamnya para staff, karyawan, dan para klien.

\subsection{Kontribusi Praktis}

a. Meningkatkan nilai moralitas dalam pribadi setiap auditor.

Dalam hal ini, para akuntan dituntut untuk mempunyai kompetensi yang sesuai dengan profesinya. Hal ini dimaksudkan bukan hanya semata - mata peningkatan mutu dalam hal teknis atau pengetahuan saja, akan tetapi termasuk juga dalam hal moralitas yang ditanamkan dalam setiap akuntan sejak dini, sehingga dengan adanya sikap moralitas akan membangun sikap kesadaran diri yang akan menjadi kebiasaan untuk dapat berbuat jujur dan adil dalam melakukan setiap penugasan.

b. Pentingnya penerapan sanksi yang tegas bagi akuntan yang melanggar.

Pentingnya akan peraturan dan sanksi yang tegas untuk setiap akuntan dapat membantu menunjang sikap profesionalitas para akuntan dalam bekerja sesuai dengan kode etik profesi akuntan yang hasilnya untuk melayani kepentingan publik.

c. Melakukan sosialisasi dan edukasi terhadap para mahasiswa/i mengenai profesi akuntan publik.

Mengadakan pengedukasian terlebih dahulu bagi para calon akuntan mengenai pendidikan etika sebelum memasuki profesi sebagai akuntan, karena tuntutan perkembangan zaman negara ini membutuhkan para akuntan publik yang memiliki sikap kompeten, independen sehingga menghasilkan sikap profesionalitas dalam bekerja untuk melayani kepentingan publik.

\section{DAFTAR PUSTAKA}

Adian, Donny Gahral (2010), Pengantar Fenomenologi, Cetakan 1, Depok : Koekoesan.

Anthony Giddens. 2011. The Constitution of Society . Cetakan keempat. Yogyakarta: Pedati

Burrel, Gibson. dan Gareth. Morgan, (1979). Sosiological Paradigms and Organizational Analysis. London : Heinemann Educational Books Ltd.

Creswell, John W. (2007). Qualitative Inquiry \& Research Design Choosing Among Five Approaches. London: Sage Publication.

Elder, R.J., Beasley, M.S., Arens, A.A., \& Jusuf A.A. (2013), Jasa Audit dan Assurance: Pendekatan Terpadu (Adaptasi Indonesia), Jakarta: Salemba Empat.

John Roberts. 1985. Accounting Systems And Systems Of Accountability- Understanding Accounting Practices In Their Organisational Contexts. Great Britain : Pregamon Press LTD.

Moleong, Lexy J. (2014). Metodologi Penelitian Kualitatif, Bandung : Remaja Rosdakarya 
Roslender, Robin and Jesse. F. Dillard. (2003). Reflections on The Interdisciplinary Perspectives on Accounting Project, New York : Elsevier Science Ltd.

Windsor, C.A. dan N.M. Ashkanasy (1995). "The Effect of Client Management Bargaining Power, Moral Reasoning Development, and Belief in a Just World on Auditor Independence", Accounting, Organizations and Society, Vol 20. No. 7/8, hal 701-720.

\section{LAMPIRAN}

Tabel 1.1 Hasil Penelitian Konflik Penyesuaian Audit.

\begin{tabular}{|c|c|c|c|c|c|}
\hline No & $\begin{array}{c}\text { Temuan } \\
\text { Audit }\end{array}$ & Sisi Auditor & Analisis & Sisi Klien & Analisis \\
\hline 1. & $\begin{array}{l}\text { Di dalam } \\
\text { biaya pra } \\
\text { operasi } \\
\text { terdapat biaya } \\
\text { berupa } \\
\text { community } \\
\text { development } \\
\text { yang sangat } \\
\text { material dalam } \\
\text { laporan } \\
\text { keuangan yaitu } \\
\text { sebesar } 24 \\
\text { Milyar rupiah. }\end{array}$ & $\begin{array}{l}\text { Pertimbangan } \\
\text { materialitas }\end{array}$ & $\begin{array}{l}\text { Temuan audit } \\
\text { adalah } \\
\text { material dan } \\
\text { harus } \\
\text { dilakukan } \\
\text { penyesuaian } \\
\text { dengan standar } \\
\text { pencatatan } \\
\text { yang ada. }\end{array}$ & $\begin{array}{l}\text { Dampak } \\
\text { Potensial } \\
\text { Kehilangan } \\
\text { Investor }\end{array}$ & $\begin{array}{l}\text { Klien ingin biaya } \\
\text { tersebut tidak dijadikan } \\
\text { expense terlebih dahulu } \\
\text { tetapi menunggu } \\
\text { perusahaan beroperasi } \\
\text { dan baru diidentifikasi. } \\
\text { Klien menginginkan } \\
\text { biaya tersebut tetap } \\
\text { dijadikan aset lain lain } \\
\text { karena apabila dijadikan } \\
\text { beban maka laporan } \\
\text { keuangan perusahaan } \\
\text { terihat tidak bagus dan } \\
\text { investor menjadi tidak } \\
\text { tertarik untuk } \\
\text { berinvestasi }\end{array}$ \\
\hline 2. & $\begin{array}{l}\text { Ditemukan } \\
\text { project under } \\
\text { construction } \\
\text { yang } \\
\text { merupakan } \\
\text { biaya pra } \\
\text { operasi yang } \\
\text { disajikan dan } \\
\text { diungkapnkan } \\
\text { secara tidak } \\
\text { tepat. }\end{array}$ & $\begin{array}{l}\text { Asersi } \\
\text { Manajemen } \\
\text { Penyajian dan } \\
\text { Pengungkapan }\end{array}$ & $\begin{array}{l}\text { Jika biaya ini } \\
\text { dikapitalisasi } \\
\text { partner tidak } \\
\text { yakin akan } \\
\text { memberikan } \\
\text { penyajian dan } \\
\text { pengungkapan } \\
\text { yang tepat } \\
\text { bagi pengguna } \\
\text { laporan } \\
\text { keuangan, } \\
\text { karena aset } \\
\text { lain-lain ini } \\
\text { tidak bisa } \\
\text { diidentifikasi. }\end{array}$ & $\begin{array}{l}\text { Penghindaran } \\
\text { Pajak }\end{array}$ & $\begin{array}{l}\text { Klien tidak mau } \\
\text { dikoreksi karena ada } \\
\text { kepentingan perpajakan } \\
\text { didalamnya yaitu seperti } \\
\text { takut akan diperiksa jika } \\
\text { loss besar dan } \\
\text { memanfaatkan kerugian } \\
\text { perpajakan di kemudian } \\
\text { hari. }\end{array}$ \\
\hline
\end{tabular}




\begin{tabular}{|c|c|c|c|c|c|}
\hline No & $\begin{array}{c}\text { Temuan } \\
\text { Audit }\end{array}$ & Sisi Auditor & Analisis & Sisi Klien & Analisis \\
\hline 3. & $\begin{array}{l}\text { Temuan audit } \\
\text { yang } \\
\text { didapatkan } \\
\text { adalah biaya } \\
\text { community } \\
\text { development } \\
\text { yang berada di } \\
\text { dalam project } \\
\text { under } \\
\text { construction } \\
\text { sebesar 24 M } \\
\text { memiliki } \\
\text { dokumen } \\
\text { pendukung } \\
\text { yang tidak } \\
\text { memadai }\end{array}$ & $\begin{array}{l}\text { Kompetensi } \\
\text { Bukti }\end{array}$ & $\begin{array}{l}\text { Partner } \\
\text { meminta untuk } \\
\text { untuk minimal } \\
\text { ada dokumen } \\
\text { pendukung } \\
\text { dari pihak } \\
\text { internal untuk } \\
\text { memastikan } \\
\text { bahwa bukti } \\
\text { audit tersebut } \\
\text { kompeten } \\
\text { untuk } \\
\text { mendukung } \\
\text { opini yang } \\
\text { akan diberikan } \\
\text { oleh partner } \\
\text { dan dapat } \\
\text { dipertimbangk } \\
\text { an mengenai } \\
\text { biaya tersebut. }\end{array}$ & $\begin{array}{l}\text { Penghindaran } \\
\text { Hukum }\end{array}$ & $\begin{array}{l}\text { Biaya tersebut akan } \\
\text { dijadikan biaya research } \\
\text { and development tetapi } \\
\text { susah untuk di sajikan } \\
\text { secara jelas di laporan } \\
\text { audit karena } \\
\text { menyangkut perkara } \\
\text { hukum yaitu suap, } \\
\text { sehingga klien } \\
\text { menghindari masalah } \\
\text { hukum yang akan } \\
\text { dihadapi jika } \\
\text { menyajikan laporan } \\
\text { keuangan tersebut } \\
\text { secara detail. }\end{array}$ \\
\hline 4. & $\begin{array}{l}\text { Tujuan laporan } \\
\text { audit untuk } \\
\text { pihak internal } \\
\text { atau eksternal }\end{array}$ & $\begin{array}{l}\text { Tanggung } \\
\text { Jawab Auditor }\end{array}$ & $\begin{array}{l}\text { Jika tujuan } \\
\text { pelaporan } \\
\text { untuk } \\
\text { kalangan } \\
\text { sendiri maka } \\
\text { saya akan } \\
\text { mempertimban } \\
\text { gkan untuk } \\
\text { mengikuti } \\
\text { kemauan klien } \\
\text { tetapi jika } \\
\text { untuk pihak } \\
\text { eksternal saya } \\
\text { tidak bisa } \\
\text { membantu. }\end{array}$ & $\begin{array}{l}\text { Tanggung } \\
\text { Jawab } \\
\text { kepada Pihak } \\
\text { Eksternal }\end{array}$ & $\begin{array}{l}\text { Pihak eksternal yang } \\
\text { akan berinvestasi akan } \\
\text { melihat laporan } \\
\text { keuangan perusahaan } \\
\text { dan mempengaruhi } \\
\text { dalam pengambilan } \\
\text { keputusan sehingga } \\
\text { klien tidak ingin terjadi } \\
\text { loss yang besar. }\end{array}$ \\
\hline 5. & $\begin{array}{l}\text { Untuk biaya } \\
\text { community } \\
\text { development } \\
\text { sesuai dengan } \\
\text { PSAK 19, } \\
\text { yang termasuk } \\
\text { dalam biaya } \\
\text { pra operasi } \\
\text { seperti izin } \\
\text { perusahaan } \\
\text { harus } \\
\text { dibebankan } \\
\text { pada saat } \\
\text { terjadinya }\end{array}$ & $\begin{array}{l}\text { Standar } \\
\text { Pelaporan }\end{array}$ & $\begin{array}{l}\text { Penerapan } \\
\text { PSAK ke dalam } \\
\text { bisnis memang } \\
\text { sulit karena } \\
\text { praktek bisnis di } \\
\text { Indonesia dan } \\
\text { keberagaman } \\
\text { dalam bisnis } \\
\text { dan penyesuaian } \\
\text { dengan PSAK, } \\
\text { Partner mengerti } \\
\text { bahwa dalam } \\
\text { bisnis penerapan } \\
\text { PSAK 100\% } \\
\text { memang sulit. }\end{array}$ & $\begin{array}{l}\text { Kesalahan } \\
\text { Klasifikasi }\end{array}$ & $\begin{array}{l}\text { Klien salah } \\
\text { mengklasifikasikan } \\
\text { biaya pra operasi } \\
\text { dijadikan aset tidak } \\
\text { lancar, dikarenakan } \\
\text { belum mengetahui } \\
\text { adanya perubahan } \\
\text { standar akuntansi } \\
\text { terbaru yang } \\
\text { mengharuskan } \\
\text { pembebanan biaya pra } \\
\text { operasi pada saat } \\
\text { terjadinya }\end{array}$ \\
\hline
\end{tabular}




\begin{tabular}{|c|c|c|c|c|c|}
\hline No & $\begin{array}{c}\text { Temuan } \\
\text { Audit }\end{array}$ & Sisi Auditor & Analisis & Sisi Klien & Analisis \\
\hline 6. & $\begin{array}{l}\text { Ketidaksesuaia } \\
\text { n pencatatan } \\
\text { klien dengan } \\
\text { PSAK } \\
\text { mengenai } \\
\text { biaya pra } \\
\text { operasi }\end{array}$ & $\begin{array}{l}\text { Prinsip Etika } \\
\text { Profesionalisme }\end{array}$ & $\begin{array}{l}\text { Jika temuan } \\
\text { audit harus } \\
\text { disesuaikan } \\
\text { persis dengan } \\
\text { PSAK maka } \\
\text { pasti akan } \\
\text { disesuaikan } \\
\text { karena } \\
\text { menyangkut } \\
\text { dengan masalah } \\
\text { profesionalisme }\end{array}$ & & \\
\hline 7 & $\begin{array}{l}\text { Penyelesaian } \\
\text { Konflik } \\
\text { Temuan Audit }\end{array}$ & $\begin{array}{l}\text { Peran Auditor } \\
\text { yang Proaktif }\end{array}$ & $\begin{array}{l}\text { Partner } \\
\text { memutuskan } \\
\text { untuk } \\
\text { mereclass } \\
\text { biaya } \\
\text { community } \\
\text { development } \\
\text { tersebut } \\
\text { menjadi uang } \\
\text { muka } \\
\text { pembangunan } \\
\text { infrastruktur. }\end{array}$ & $\begin{array}{l}\text { Tanggapan } \\
\text { Klien yang } \\
\text { Reaktif }\end{array}$ & $\begin{array}{l}\text { Tindakan formal } \\
\text { dilakukan klien saat } \\
\text { tahap awal negosisasi, } \\
\text { mereka akan } \\
\text { memberikan alasan } \\
\text { formal mereka } \\
\text { melakukan } \\
\text { penyimpangan tersebut. } \\
\text { Kemudian Klien } \\
\text { memberikan alasan yang } \\
\text { mendukung kepentingan } \\
\text { klien dalam tindakan } \\
\text { non formal dalam proses } \\
\text { negosiasi dengan } \\
\text { auditor. }\end{array}$ \\
\hline
\end{tabular}

